\title{
Potentials of the Forest Resources in Adaptation to Climate Variability and Change in the North Nguu Mountain Block
}

\author{
Magreth S. Bushesha ${ }^{1}$, Peter Mjata ${ }^{2}$ \\ ${ }^{1}$ Department of Geography, Faculty of Arts and Social Sciences, The Open University of Tanzania, Dar es Salaam, Tanzania \\ ${ }^{2}$ Independent Scholar, Dar es Salaam, Tanzania
}

\section{Email address:}

magrethbushesha@yahoo.com (M. S. Bushesha)

\section{To cite this article:}

Magreth S. Bushesha, Peter Mjata. Potentials of the Forest Resources in Adaptation to Climate Variability and Change in the North Nguu Mountain Block. International Journal of Environmental Protection and Policy. Vol. 4, No. 6, 2016, pp. 178-186. doi: 10.11648/j.ijepp.20160406.14

Received: September 1, 2016; Accepted: November 12, 2016; Published: January 5, 2017

\begin{abstract}
The study intended to establish potentials of forests in adaptation to climate change with references to North Nguu Mountain block communities. The major questions to be answered were as follows: 1 . How do forests in the north Nguu Mountain blocks buffer local people to the impacts of climate change? 2. What resources are taped from the forests as a way to adapt to climate variability and change in the study area? To collect data, a questionnaire was administered to a sample population. Also focus groups discussions were conducted in the study villages and finally in-depth interviews with key informants were also usedto collect data. Content analysis was used to analyze collected data. Findings show that people living adjacent to the North Nguu Forests uses forests goods and services as buffers to the impacts of climate change. Resources that are taped from the forests are those that enable communities diversify and broaden their livelihood horizons; these include arable land, timber as well as the non-timber forest productssuch as wild fruits, berries, nuts and vegetables, honey, medicinal plants, grazing fields, game and game products, mining as well as water sources. Local people also benefit from conducive weather conditions i.e. sufficient and timely rainfall events accompanied with moderate temperatures. The study concludes that forests play a significant role in adaptation to climate change in the study area. However, the study also concludes that although most people use forests products and services to improve income and hence the general well being, they poorly conceive the relationship between forests and climate change. This has negative implications on sustainable forest resources use where over utilization and the general forests degradation are likely. The study therefore suggests that policy intervention is urgently required to promote sustainable resources utilization which in turnwill lead to increase of resources taped from the forests for adaptation to climate variability and change.
\end{abstract}

Keywords: Adaptation to Climate Change, Forest Resources, North Nguu Mountain Block, Hunting and Gathering

\section{Introduction}

Forests can play a role in adaptation to climate change by helping human societies to stabilize resilience in adapting to climate change (FAO 2007). Forests may also serve as a source of resilience by providing resources to local populations and through forest landscape, design to protect communities from increasingly erratic weather (Larson et al. 2007). By virtue of their importance as habitats, forests are integral to conserving biological diversity and ecosystems with provision of livelihoods (UNEP, 2001; Agrawala, et al, 2003). Furthermore, remnant trees in pastures andagricultural fields provide habitat and resources that are otherwise absent from other landscapes. In defining climate change, this study adopted a definition by Alley et al, (2007) who defines climate change asa change of climate that is attributed directly or indirectly to human activity that alters the composition of the global atmosphere which is in addition to natural climate variability observed over comparable time periods.

Empirical case studies on adaptation to climate change indicate that regular supply of goods and services from 
forestsprovide sustainable adaptation options for climate variability and change. A study by Gordana (2009) for example, indicate that forest resources in the Prespa Park region connecting Macedonia, Greece and Albania in Europe played a significant role in adaptations to climate variability and change for local people;degradation of the park had profound impact on local peoples'livelihood in the area. Gordana (2009) taped such experiences through extended field research and case studies. Although there is no mention of paradigms models and theories developed through the Prespa Park study, still the methodology and approaches used i.e. visiting families, tourists and business community were worth noting. Gouri (2004) noted that, forests played an important role in adaptation to climate variability and change for people in Himachal Pradesh although taping of such resources led to a serious degradation of the forests and hence the country endured persistent rural poverty. Using interviews as the main source of information, Harvey and Haber (1999), concluded that the disappearance of natural forests in Costa Rica (which was partly accelerated by climate change) jeopardized opportunities for adaptation to climate change in the two countries.

White (2002) also commentedthat given the strong relationship between the forest and climate change, globally, there had been intensive investments into managing the forest resource as diversified adaptation strategies to benefit more with a regular supply of goods and services from the forest ecosystem. In line with White (2002), AWF (2003) for example reports that the government of Kenya re-afforested huge forest blocks in Samburu Heartland in Northern Kenya which were formerly seriously degraded. Today, forests keep locals in the Samburu Heartland safe from the impacts of climate change as they provide them with health options for adaptation during bad conditions (AWF 2003).

In Tanzania, experiences also show that forest resources have played an important role in adaptation to climate variability and change. Siege et al, in AWF (2003), reports that people residing adjacent to Selous Game Reserve opted to forestry resources as a way to buffer themselves from the effects of climate change. However the forest habitat for wildlife came under pressure and was deteriorating faster. Harvests from the hunting quota system started to go down. In turn, communities in the area started to experience unsustainable livelihood, low income and consistently being pushed to poverty. In Lushoto District, adaptations to climate change in the district resulted to competition in utilization of forest products. This led to deterioration of the forest resource in the district hence scarcity of forest products in the area was experienced.

The North Nguu Mountain block is a succession of natural forest-top mountains that form part of the Eastern Arc Mountains in Tanzania. The existing literature show that the mountains are paramount for economic, social and cultural roles in the area (UNEP, 2001; Kingdon \& Howell, 1993) where apart from providing shelter to game with an open ground for mining, the forestsalso provide a variety of livelihoods such as crop farming, and pasturesfor livestock (HIAP, 2000: UNEP, 2001; Agrawala, et al, 2003). Moreover, the forests benefits surrounding communities through government-community Joint Forest Managementwhereby communities in the NorthNguu Mountain block have access and user rights to the forest.

However, despite the importance of the forests in the North Nguu mountain block in terms of biological diversity conservation and economic and social cultural functions identified above; also despite the wide acknowledgement that climate change has impacts on forests and peoples' livelihoods described in the reviewed literature, the existing literature does not provide sufficient information on the role of forests in the North Nguu in adaptation to climate change. The literature also falls short on how adaptation to climate variability and change has impacted such forests. HIAP, (2000) for example mentions that The North Nguu forest is being degraded through hunting and gathering activities, clearing for crop cultivation and taking livestock herds inside the forest for pasture and water; the two studies did not give a clear link between those forest destructive activities and adaptation to climate variability and change. In addition to that, the literature does not inform on the extent to which people in the study area perceive the relationship between forests and climate variability and change impacts (i.e. whether people clearly understand the roles that forests play in relieving them from the impacts of climate variability and change). Not only that but also most literature is as old as over fifteen years and above - a temporal scale likely to have many social, economic, political and cultural issues to have occurred and change what was presented as facts during the time of documentation; hence updating the literature is important. All These facts compelled the researchers to undertake this study. The study intended to answer such questions as; how do forests in the north Nguu Mountain blocks buffer local people to the impacts of climate variability and change? What resources are taped from the forests as a way to adapt to climate variability and change in the study area? Filling these knowledge gaps was considered paramount in policy formulation and implementation.

\section{Methodology}

\subsection{The Study Area}

The North Nguu Mountain block in Kilindi district lies within an altitude ranging from $500-1800 \mathrm{~m}$ above sea level. Most of the area is covered by hills and mountains. A mentioned earlier, the North Nguu Mountain block forms part of the Eastern Arc Mountain ranges a chain of ancient crystalline mountains near the Indian Ocean that stretch out across east of Kenya and Tanzania crossing in the middle of Kilindi District. Consisting of about eleven (11) separate submontane grading forest-top free standing mountains with a large range in altitude of about $1,620 \mathrm{~m}$ a.s.1 and rainfall of 
about $375 \mathrm{~mm}$, the mountain-top forest belt of The North Nguu Mountain block is the most important habitat in terms of ecosystem of vegetation types and species diversity.
Figure 1 presents a sketch of the North Nguu Mountain block.

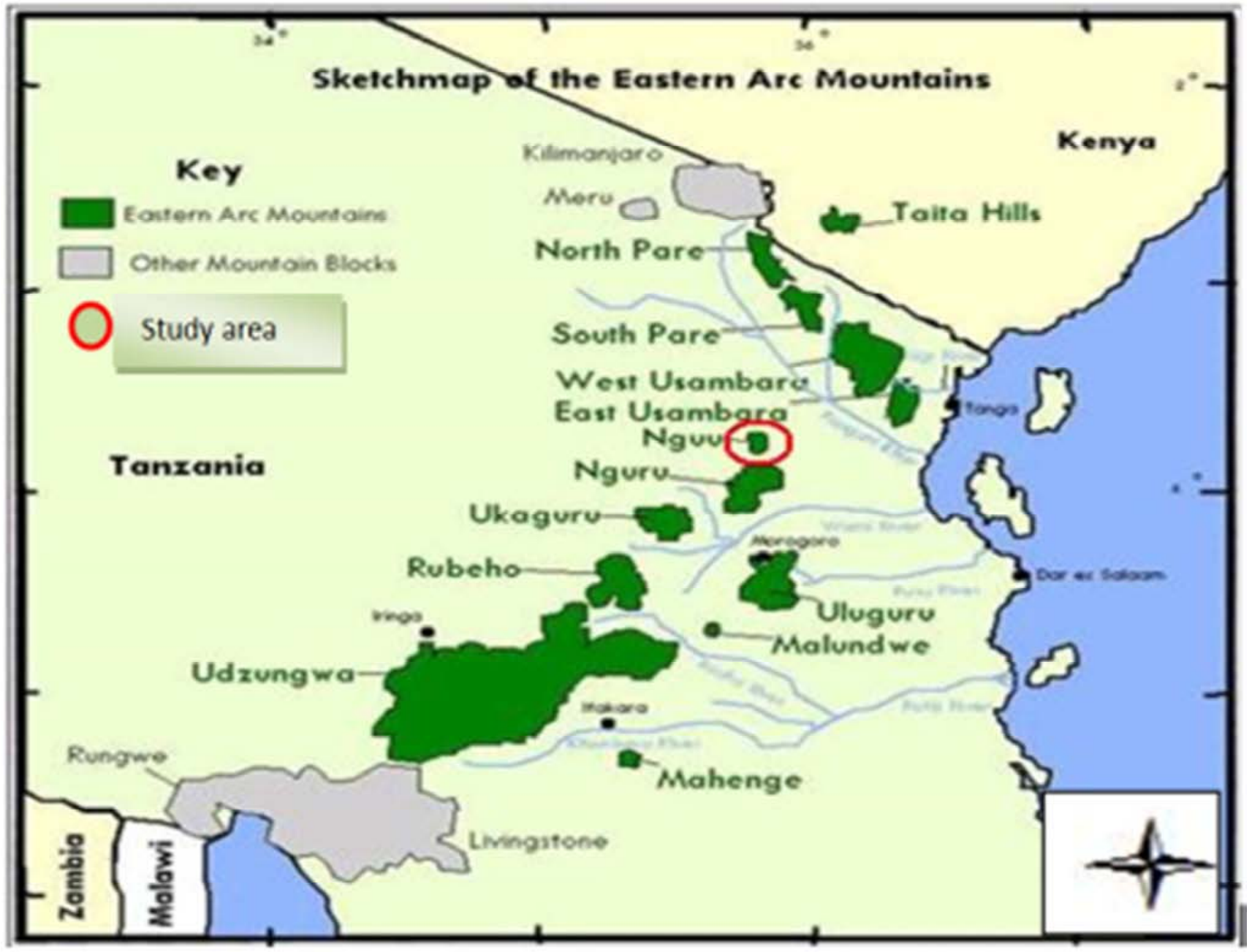

Source: Eastern Arc Mountains - Kingdon\& Howell, 1993

Figure 1. Sketch position of the North Nguu Mountain block.

Table 1 presents the mountain-top forest base of The North Nguu Mountain block.

Table 1. The mountain-top forest base of The North Nguu Mountain block

\begin{tabular}{lll|l}
\hline Mountain & Altitude (m) a.s.l. & Location & Top Forest Cover (Ha) \\
\hline Bondo & 1,011 & $5^{0} 47 \mathrm{~S}, 37^{0} 28 \mathrm{E}$ & 328 \\
Jungu & 1,230 & $4^{0} 27-4^{0} 38 \mathrm{~S}, 37^{0} 36-37^{0} 32 \mathrm{E}$ & 369 \\
Kilindi & 1,520 & $5^{0} 33-5^{0} 40 \mathrm{~S}, 37^{0} 33-37^{0} 36 \mathrm{E}$ & 4,299 \\
Kwediboma & 1,300 & $5^{0} 26 \mathrm{~S}, 37^{0} 33 \mathrm{E}$ & 285 \\
Mbwegere & 1,160 & $5^{0} 45 \mathrm{~S}, 37^{0} 29 \mathrm{E}$ & 368 \\
Mkongo & 1,130 & $5^{0} 27-5^{0} 29 \mathrm{~S}, 37^{0} 33 \mathrm{E}$ & 985 \\
Mkuli & 1,260 & $5^{0} 47 \mathrm{~S}, 37^{0} 28 \mathrm{E}$ & 2,931 \\
Nderema & 1,620 & $5^{0} 42-5^{0} 37-5^{0} 37 \mathrm{~S}, 37^{0} 32-37^{0} 27 \mathrm{E}$ & 3,928 \\
North Nguu & 1,550 & $5^{0} 27-5^{0} 38 \mathrm{~S}, 37^{0} 36-37^{0} 32 \mathrm{E}$ & 14,042 \\
Pumula & 1,160 & $5^{0} 40-5^{0} 44 \mathrm{~S}, 37032-37^{0} 28 \mathrm{E}$ & 1,062 \\
\hline
\end{tabular}

Source: Forest department - KilindiDisttrict, Tanzania (2012).

Kilindi district is located within latitudes $50^{\circ} 18^{\prime}$ and $50^{\circ} 48^{\prime}$ south of the equator and longitude $37^{\circ}$ and $38^{\circ} 45^{\prime}$ east of the Greenwich prime meridian in northeast Tanzania (Figure 2). The district covers a total of $6,129 \mathrm{~km}^{2}$. This study was conducted in four villages Kwediboma, Kilindi, Gombero and Lulago villages within the North Nguu Mountain block in Kilindi district of Tanzania. Table 2 presents location and area coverage of the study villages. 


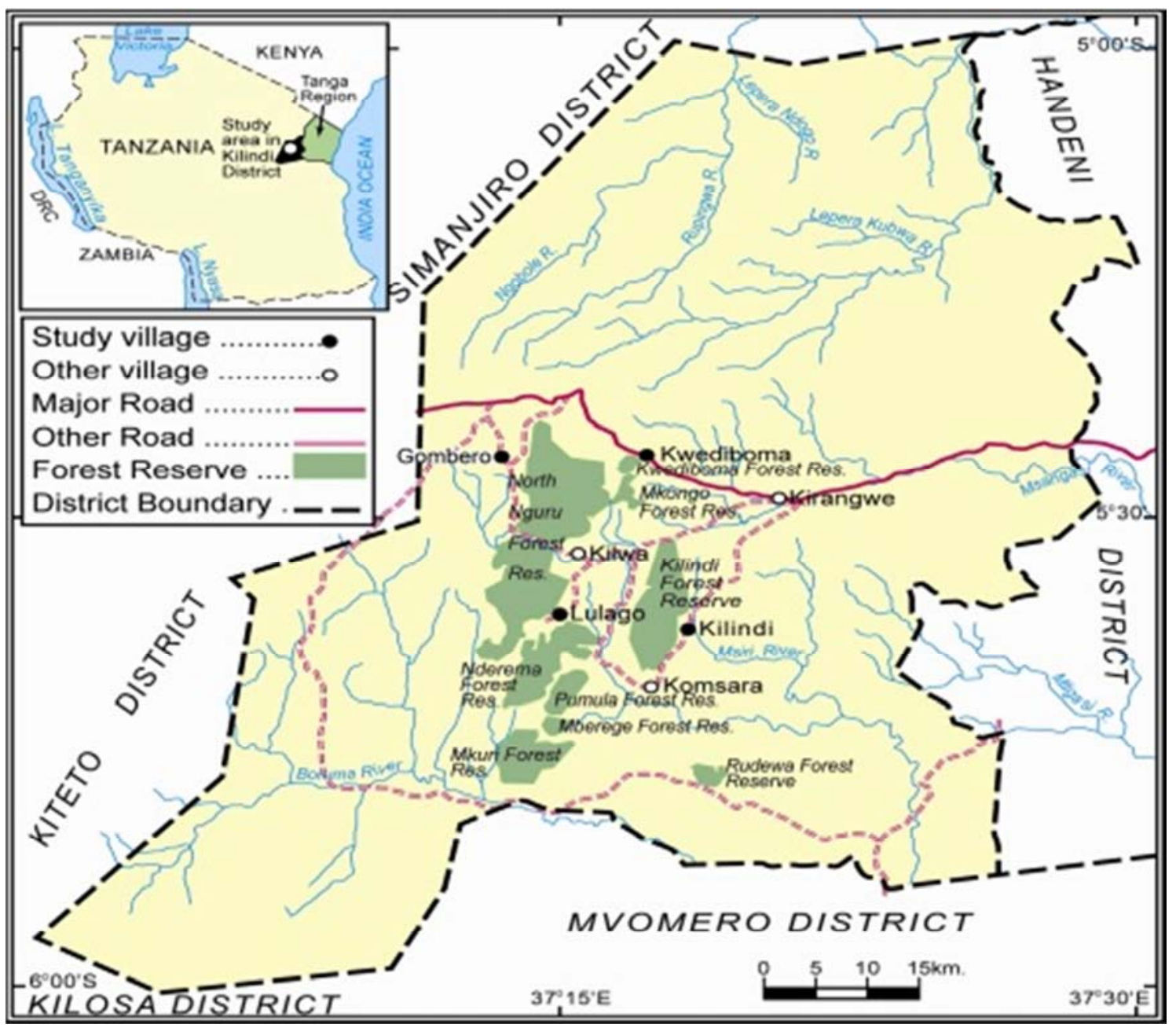

Figure 2. The study area in Kilindi district. Tanzania.

Table 2. Location and area coverage of the study villages.

\begin{tabular}{llll}
\hline Village & \multicolumn{2}{l}{ The Forestcoverage (Ha) } & Location of the forest \\
\hline $\begin{array}{l}\text { Gombero } \\
\text { Lulago }\end{array}$ & North Nguu FR & $13,911.7$ & $\begin{array}{l}5027-5038 \mathrm{~S} 37036- \\
37032 \mathrm{E}\end{array}$ \\
Kilindi & Kilindi FR & 4,299 & $\begin{array}{l}5033-5040 \mathrm{~S} 37033- \\
37036 \mathrm{E}\end{array}$ \\
Kwediboma & Kwediboma FR & 284.9 & $\begin{array}{l}5033-5040 \mathrm{~S} 37033- \\
37036 \mathrm{E}\end{array}$ \\
\hline
\end{tabular}

Source: Kilindi District Forest Office - KilindiDistrict, Tanzania (2012).

\subsection{The Study Population and Methodology}

This study adopted a case study research design. The population in the study area shows an increasing trend where by 1960 s most villages had a population of about 100 people but by 2011 most study villages have more than 2000people (table 3 ). From the table it can be clearly realized that while the area had a total of 406 people, by 2011 the area had a total of 11,956 people that means the population had increased by more than twenty-nine times within 49 years which actually is alarming.

Table 3. Population trend in the study villages: $1962-2011$.

\begin{tabular}{|c|c|c|c|c|c|c|c|c|c|c|c|c|c|c|c|}
\hline & \multicolumn{3}{|c|}{ Kilindi } & \multicolumn{3}{|c|}{ Kwediboma } & \multicolumn{3}{|c|}{ Lulago } & \multicolumn{3}{|c|}{ Gombero } & \multicolumn{3}{|c|}{ GRAND TOTAL } \\
\hline & $\mathbf{F}$ & $\mathbf{M}$ & Total & $\mathbf{F}$ & M & Total & $\mathbf{F}$ & $\mathbf{M}$ & Total & $\mathbf{F}$ & $\mathbf{M}$ & Total & $\mathbf{F}$ & M & Total \\
\hline 1962 & 52 & 46 & 98 & 66 & 59 & 125 & 43 & 35 & 78 & 56 & 49 & 105 & 217 & 189 & 406 \\
\hline 1972 & 293 & 285 & 57 & 491 & 498 & 989 & 247 & 239 & 486 & 333 & 330 & 663 & 1,364 & 1,352 & 2,716 \\
\hline 1982 & 538 & 520 & 1,058 & 931 & 922 & 1,853 & 451 & 443 & 894 & 615 & 606 & 1,221 & 2,535 & 2,491 & 5,026 \\
\hline 1992 & 779 & 759 & 1,538 & 1,366 & 1,351 & 2,717 & 657 & 645 & 1,302 & 897 & 882 & 1,779 & 3,699 & 3,637 & 7,336 \\
\hline 2002 & 1,021 & 997 & 2,018 & 1,800 & 1,781 & 3,581 & 862 & 848 & 1,710 & 1,181 & 1,156 & 2,337 & 4,864 & 4,782 & 9,646 \\
\hline 2011 & 1,264 & 1,234 & 2,498 & 2,236 & 2,209 & 4,445 & 1,067 & 1,051 & 2,118 & 1,464 & 1,431 & 2,895 & 6,031 & 5,925 & 11,956 \\
\hline
\end{tabular}

A total of $1,250(10 \%)$ people formed the sample size for this study out of whom 631 were females and 619 were males. The sample was selected purposively to balance such social profiles as sex, age and educational levels. The selected sample populationwas comprised of crop farming communities, livestock keepers, traders, hunters and 
communities which engage in collecting from the forest for their livelihoods. Primary data was collected through interview, focus group discussion, observation and documentary review. Numerical data was analyzed using simple descriptive statistical approach with the help ofStatistical Package for Social Sciences (SPSS) computer soft ware; qualitative data on the other hand was analyzed using content analysis approach.

\section{Findings and Discussion: Forests as Buffers to the Impacts of Cliamte Variability and Change}

People in the study area perceive that climate change has led to such impacts as decreased water resources, poor soils, decreased timber resources, decreased moisture, and decreased pasture. People however noted that forests in the North Nguu Mountains still play a huge role in buffering locals to such impacts of climate variability and change. Among others, forests are perceive to be sources of land for agriculture, water, moisture, timber, pastures, raw materials for decorations processing units and game meats.

\subsection{Land for Agriculture}

During focus discussions group members explained that forests offer opportunities for farm expansion. Usually farmers clear forests and open up new areas for agriculture. Likewisedata from the questionnaire show thatatotal of $30.1 \%$ of all respondents indicated that forests provide room for expansion and/or opening up of new farms. In Kwedibomavillage, for example, members of the FGD members agreed that most farms in the study area are no longer productive due to prolonged periods of drought; as a resultpeople clear forests toeither expand or open up new farms and/or grazing fields.

\subsection{Provision of Grazing Field}

Findings show that $31 \%$ of all respondents indicated that, forests offer grazing fields since folder and pasture in communal lands as well as in households owned land is scarce partly due to increased lengths of dry seasons.

\subsection{Provision of Water Sources}

Findings revelthat $16 \%$ of all respondents mentioned that forests are good water sources. Locals tape water from natural springs, rivers and waterfalls which are available in the forests. Thisrole of the forests is considered important particularly because water is scarce in the village land and such scarcity is associated with the increased span of dry seasons in the study area. A key informant from Gombero village commented that the forest provides water for livestock and crops. The key informantexplained further that there are water tributaries and water channelsoriginating from springs in the forest; from such water some people engage in supplementary traditional irrigation farming.

\subsection{Provision of Timber}

$16 \%$ of all respondents indicated that forests provide timber for different activities including building poles and fire wood. Of all observed investments in timber processing plants, $60.8 \%$ of the investors in timber processing plants were individuals, $25.5 \%$ by groups and $13.7 \%$ by families (Figure 3 ). Sale of timber (and related products) is done mostly by individuals; these are individuals with timber selling license (permits) from the relevant authorities. Timber from the forests has led to individuals and groups run carpentry industries that assist in income generation. $61.7 \%$ of the carpentry and wood working industriesare owned by individuals, $22.1 \%$ by groups and $16.2 \%$ by families (Figure 4 ).

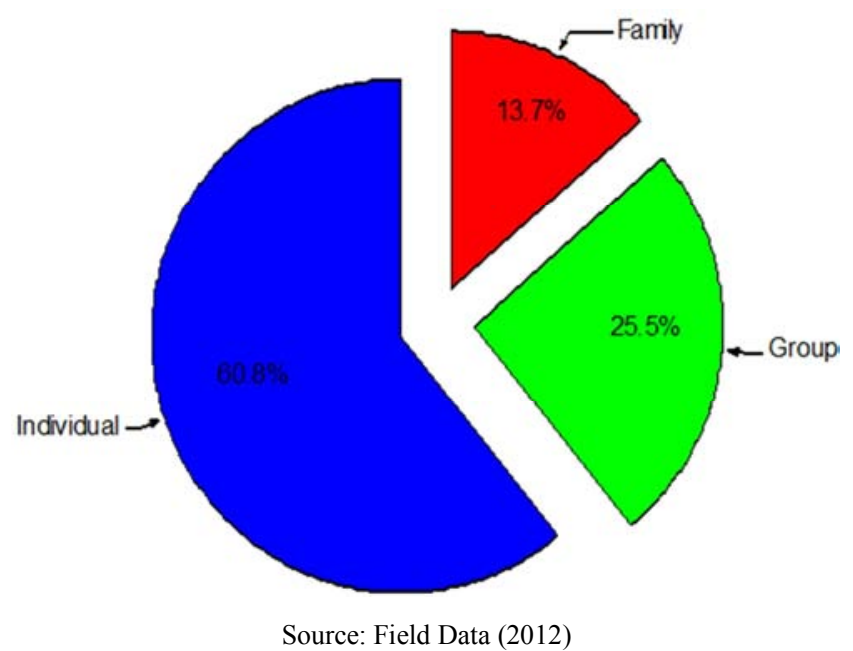

Figure 3. Ownership of timber selling plants in The North Nguu Mountain block.

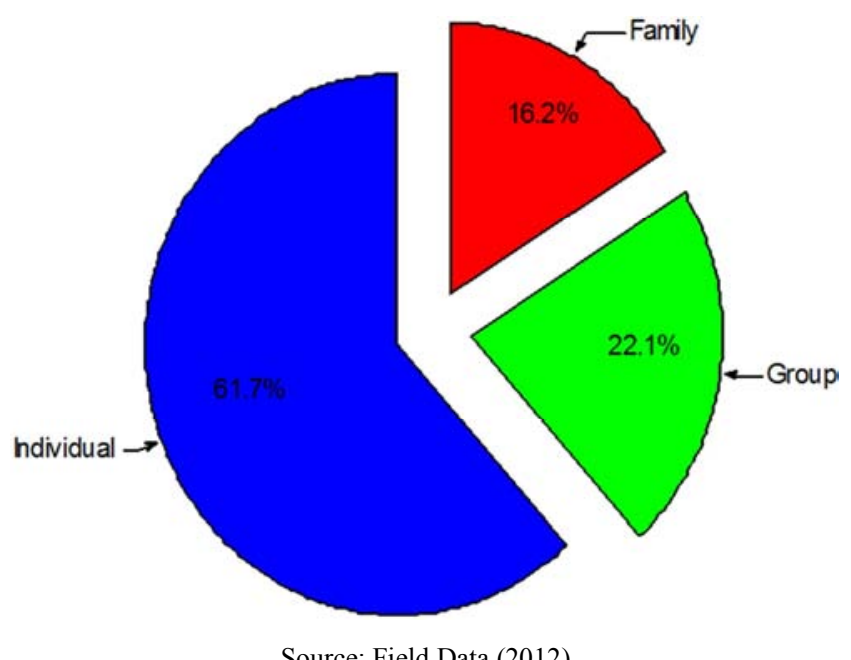

Figure 4. Ownership of carpentry and wood works plants in The North Nguu Mountain block.

Forests also provide timber for charcoal making. During focus groupdiscussion group members noted that most charcoal available in the village is a product of timber from the forests in the north nguu mountain block. A key 
informant from Lulago village for example had the following comment:

'my husband harvest timber for sale and some for making furniture for home use and some for sell I always go with him into the forest and collect firewood including wild vegetables, fruits, berries and nuts for our own use and some for selling we're making our living smoothly just because our home is standing adjacent to the forest in this village' (A farmer: Lulago village, 2011).

Charcoalis the second major source of domestic fuel throughout the study villages. A very low number of the ordinary local community use charcoal as fuel wood in the villages. Instead, most of the charcoal prepared in the villages is transported to big towns and business centers where demand for charcoal is very high for both domestic use as well as food vendors' related enterprises. It was observed also that plants for preparing charcoal are mainly livelihood or adaptation processes focused at profit making to supplement purchasing power for food and other social needs such as school and medical fees.

Implicitly timber products supports majority in the study area (even through one might not be directly involved in selling timber products yet he/she could be benefiting from timber through multiplier effects). It is surprising, however that, despite the vast contribution oftimber in the livelihoods of the people in the study area narrated in this section, only $16 \%$ of all respondents vetted that provision of timber products from the forest supports people's livelihoods. One could otherwise expect that majority of the respondents could acknowledge this important role of timber in their livelihoods since seemingly the sector is at the heart of the peoples' economy in the community in question. One importantissues can be associated with this; thatis the question that was paused to the respondents to gather this data. The question required respondents to indicated whether they agree or disagree that timber products are important resources from the forests that buffers the community from the impact of climate change. It is very likely that respondents did not associate timber harvesting and the whole issue of climate variability and change given the fact that every individuals has their own perceptions of what climate variability and change is. If this is the case then any interventions that would attempt to address challenges of climate change need to take seriously the issue of people's perceptions ofclimate variability and change, Not only that but alsohow climate variability and change is associated with social economic and political aspects of human life.

\subsection{Raw Materials for Handcrafts Industries}

Forests are considered important sources of raw materials for handcraftsindustries in the study area. More people engage in handcraft industries as an option for adaptation to climate change. Data shows that $44 \%$ of all handcrafts industries and decorations processing units are owned by individuals, whereas $20 \%$ are owned by groups and $36 \%$ are owned byfamilies. Though undertaken as an income generating enterprises, handcrafts industriesare dominated mainly by women. Figure 5 presents ownership categories of the community in managing handcraft enterprises.

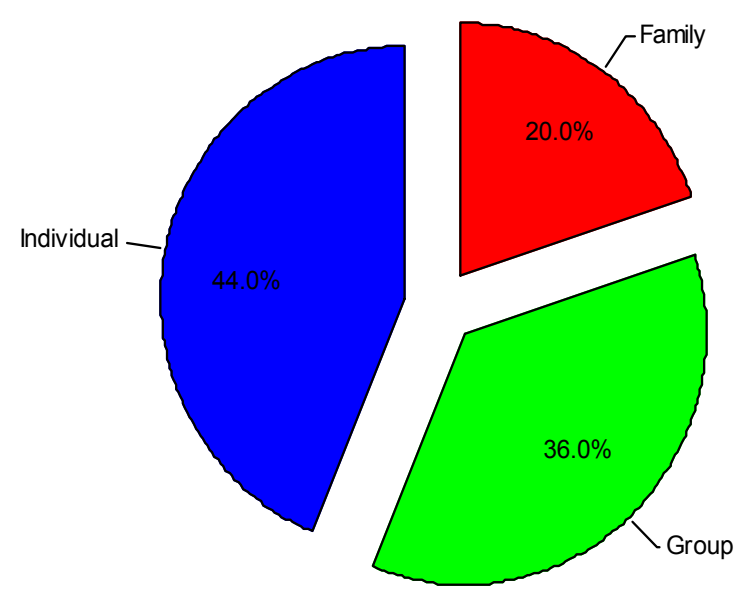

Source: Field Data (2012).

Figure 5. Handcraft enterprises ownership categoriesin The North Nguu Mountain block.

Most literature indicates that women will suffer more from the consequences of climate variability and change. It is interesting to learn that, in this particular society, handcrafts industries which form one of the important income generation sourcesis predominated by women. The is a need therefore to promote these kind of enterprises so as to reduce women vulnerability to the impacts of climate variability and change. This includes ensuring sustainable use of forest resources.

\subsection{Gathering and Hunting}

Respondentsindicated that being habitat for game, forests offer opportunities for game hunting. The hunted games are for both domestic consumption and for income generation. A key informant from Gombero village was of the opinion that game products and honey are the most profitable products for trading in the area. The key informer revealed to be engaged in collecting from the forest and bee hunting for trading. $\mathrm{He}$ declared to depend on the forest for living. $62 \%$ of all respondents strongly considered game hunting as an option for adaptation during difficult weather conditions (Table 4). Members of FGD in Kilindi concluded thatbee-hunting is an activity proved to assist many households in subsidizing income generation particularly during these times where crop failures has become popular in the village. Hunting and collection of forest products provides raw materials for trading. Table 4 further indicates that most respondents strongly agreed that farm expansion, herds grazing and fodder collectionare opportunities provided by the forest for adaptation to the impacts of climate change. 
Table 4. Climate change adaptation activities related to the forest.

\begin{tabular}{lllllll}
\hline Activity & Strongly agree & Agree & neutral & Disagree & Strongly disagree & Total \\
\hline I do game hunting & $62 \%$ & $28 \%$ & $03 \%$ & $06 \%$ & $01 \%$ & $100 \%$ \\
I expanded a farm in an area formerly a forest & $72 \%$ & $21 \%$ & $01 \%$ & $03 \%$ & $03 \%$ & $100 \%$ \\
I do honey harvesting & $56 \%$ & $16 \%$ & $06 \%$ & $20 \%$ & $02 \%$ & $100 \%$ \\
I graze herds in the forest & $43 \%$ & $31 \%$ & $11 \%$ & $07 \%$ & $08 \%$ & $100 \%$ \\
I regularly collect folder from the forest & $67 \%$ & $20 \%$ & $02 \%$ & $09 \%$ & $02 \%$ & $100 \%$ \\
Ritual activities are common in the forest & $51 \%$ & $36 \%$ & $06 \%$ & $04 \%$ & $03 \%$ & $100 \%$ \\
\hline
\end{tabular}

Source: Field data 2015.

It can be learnt here therefore that generally respondents referred to the forest as their prime livelihood asset in terms of timber and non-timber forest products and also a major provider when it came to the need to buffer from the impacts of climate change. Figures 6 and 7 present the forest top on the Nguu Mountain as observed from Gombero and Lulago villages during dry season. While from Figure 6 availability of folder is evident, Figure 7 suggests possibilities of such activities as bee keeping, wood harvesting and charcoal making; Figure $6 \& 7$ therefore justifies most respondent's claims on products harvested from the forests.

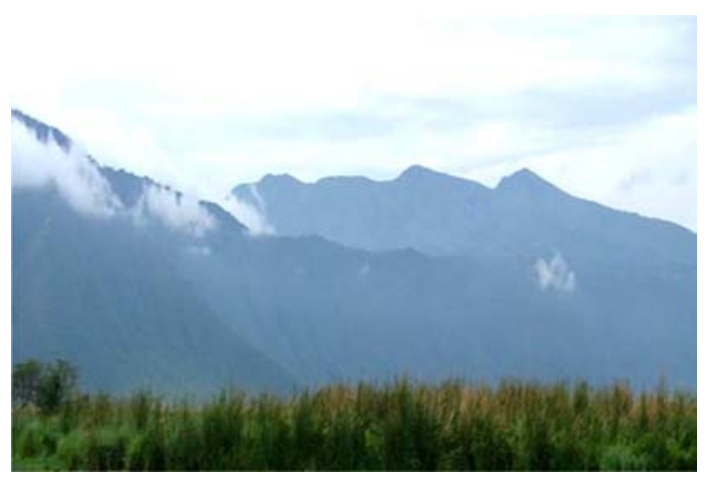

Figure 6. Showing The Ngun Mountain Forest Reserve as viewed in November 2014.

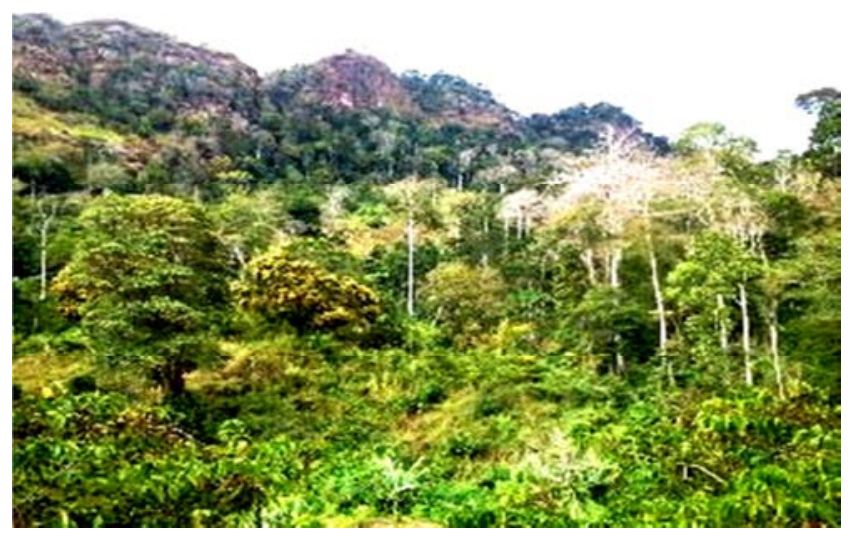

Figure 7. Showing The Nguu Mountain Forest Reserve as viewed in January 2015.

It was further reported that when collecting from the forest is not enough to support living, then such people extend the collection horizons to collecting wood and non-wood raw materials for making pots, mats, baskets etc for domestic consumption as well as for trading. The income generated from selling such products is largely used to buy food.

Of all the surveyed mud and wooden utensils plants, $62.5 \%$ of the mud bricks processing plants were owned by individuals and it was observed that $25 \%$ of the investment were owned by groups whereas, the other $12.5 \%$ of the mud and wooden utensils were owned by families. Figure 8 presents ownership and management of charcoal plants in the North Nguu Mountain block as surveyed during this study.

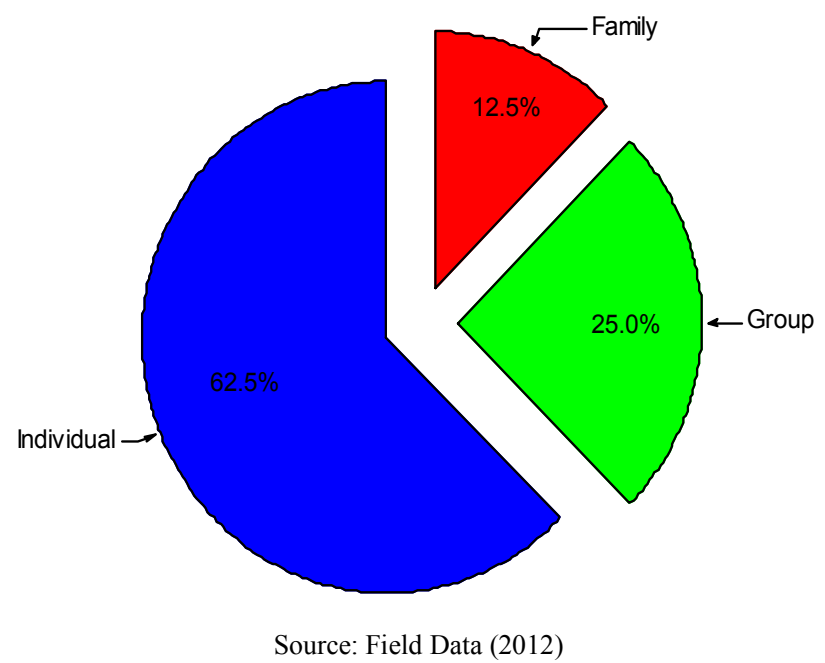

Figure 8. Ownership of charcoal plantsin The North Nguu Mountain block.

\subsection{Provision of Forest Moisture and Compost Manure}

$11.1 \%$ of all respondents indicated that the forests in the study area provide moisture. Also $11 \%$ of all respondents indicated that the forest is the source of manure. During the focus group discussion it was noted that people in the study area considered provision of moisture and manure from the forest as support for crop farming and pastures for grazing to be among the most import support they get from the forest during this time where longer dry spells are commonly experienced. Key informants argued that leafs falling from trees make good manure for their farms as opposed to farmlands away from the forest where due to increased incidents of excessive droughts there is no much leafy and grasses to be decomposed and therefore soils are getting less fertile day after day. A key informant from Kilindi village had the following to say:

'when the wind blow from the forest, moisture from the mountain top is stored in my crop farm also, when it rains, the surface runoff from the forest restores and enrich soil in 
my farm in compost manure from the mountain top forests and the fertile organic forest soil that are good for crops in my farm I also enjoy plenty of quality pasture adjacent to my farm where my cattle and my two goats graze' (A farmer: Kilindi village, 2011).

Forests are known to provide moisture to their surrounding environment. The fact that only $11 \%$ of all respondents acknowledged to benefit from forest moisture is an indication that most people in the study communityhardly objectively perceive the functioning of the forests in moisture provision. Likewise the fact that forest provision of compost was acknowledged by only $11 \%$ of all respondentsmay mean two things, i.e. either people poorly conceive the role of forests in provision of compost; or, only people with farms closer to the forest realize this kind of benefits. The findings therefore seem to suggest thatmost people in the study community may not be motivated to preserve the forests for the purposes of benefiting from moisture and compost.

\subsection{Employment Opportunities Through Managing the Forest}

Despite establishment and management of tree nurseries being connected into forest management, some youths and adults both men and women get employed seasonally to maintain (planting and re-planting) boundaries of the catchment forest reserves surrounding their villages. The employment opportunities for the youth and adults were before organized by the Forest and Beekeeping Division FBD under the Ministry of Natural Resources and Tourism in the country. he same employment opportunities were during this study being managed by the Tanzania Forest Service (TFS), a semi-autonomous government executive agency which provides legal structures and frameworks for managing forests and bee resources in the country. Such employment opportunities were also managed seasonally through the district and their respective village governments. The employment opportunities for the youth and adults apply also to community forest reserves that are managed through the district council including also village forest reserves that are managed by communities through their respective village governments. Through the temporary employments, communities benefit from the 'cut and carry' of grass, as well as, loose wood for developing wood products from inside the forests mostly done by individuals, families and or groups. Figure 9 presents results of the observed employment opportunities through managing the forest.

Of all the observed employment opportunities in managing the forest, $60 \%$ of the employees were individuals, $20 \%$ by groups and $20 \%$ family members. Employment opportunities for managing the forest was observed to be accessed more by individual youths and adults where peoples organized into communal or family groups have equal but lower chances. As revealed by communities during discussions including the formal and informal interviews, the forest particularly forest management, provided formal and informal employment opportunities in The North Nguu Mountain block. Such employment opportunities come from the various stakeholders of the forest resource in the area including communities themselves, the other stakeholders of the forest resource in the area including the government and visitors to the forest for various reasons. Furthermore, the forest provides temporary employment opportunities for communities in the area. The village secretary in Kwediboma for example said the recreation and study teams that include researchers from higher learning institutions, environmentalists and the forest ecosystem professionals, as well as, anthropologists who make part of their field studies in the area create temporary employment opportunities to people especially the youths in the village.

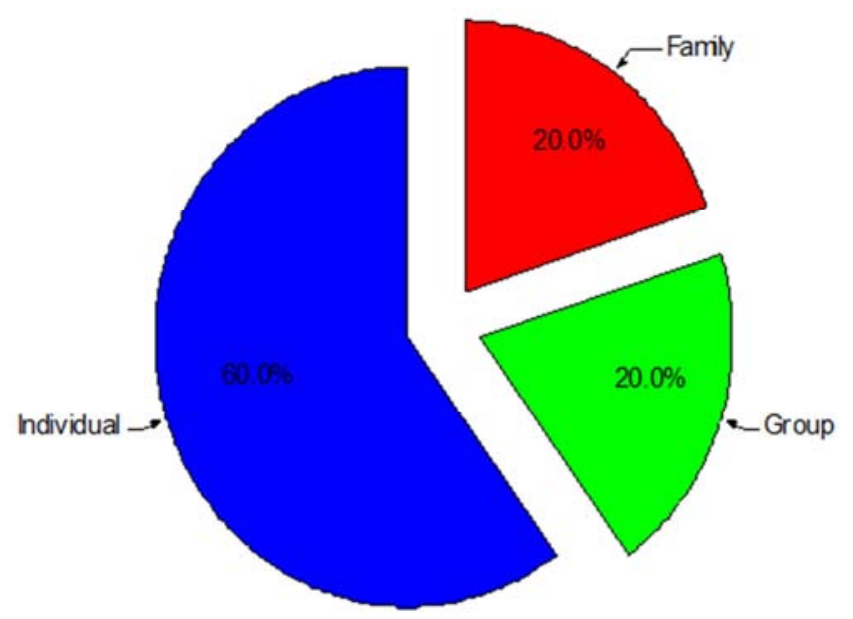

Source: Field Data (2012).

Figure 9. Employment opportunities in managing the forest.

\section{Conclusion}

It is evident from the findings thatforests in the North Nguu Mountain block play a significant role in adaptation to climate change. Land for agriculture, grazing fields, water sources, timber, game hunting and employment are all significant forms of rural livelihoods provided by the forests. That implies that non existence of forests could lead into people in the study communities suffer from limited options to adapt to variability and climate change impacts. The forests in the study communities are therefore, available assets capable of supplying a range of goods and services necessary for adaptation to climate change. The study findings, however, suggest that although most people use forest products and services to improve their household income and hence the general well being, they poorly conceive the relationship between forests and climate change. One example is that very few people indicated to realizethe functions of the forests in provision of moisture. The findings therefore mean that most people in the study area are likely not to have clear understanding of how forests influences local climates andhence implications on the likely impacts of climate change at local spatial scales. Such people are not expected to preserve such forests for the purposes of abating the impacts of climate variability and change. Poorrealization of the vast benefits of forests on reducing the impact of 
climate variability and change may lead into deforestation hence a worsenedsituation. Sanderson et al, (2012) for example pointed out thatdeforestation may lead into increased temperatures and lower humidity which have negative implications on new forest growths. Not only that but also that with reduced humid and increased temperature (enhanced with direct exposure to high sunlight levels and higher wind speeds), such forests are made prone to wild fires. In turn all this make the impact of climate variability and change even more complicated. In order for any related policy intervention to succeed, there is a need for the government and other interesting stakeholders to ensure that there is a broad understanding of the relationship between climate variability and change and forests among community members in the study area. It is important also to note findings by AWF (2003) whoreported that people residing adjacent to Selous Game Reserve opted to forestry resources as a way to buffer themselves from the effects of climate change. However, the forest habitat for wildlife came under pressure and was deteriorating faster. Harvests from the hunting quota system started to go down. In turn, communities in the area started to experience unsustainable livelihood, low income and consistently being pushed to poverty. If no urgent action taken the same is likely to be experienced in The North Nguu Mountain Block.

Furthermore, there is a need to promote women who are involved in production of timber decorative materials in order to boost them economically; however, that need to be handled with care ensuring that production of such timber decorative materials does fuel deforestation. Future studies should address questions related to how far the forest resources in the study community are suffering from anthropogenic actions which are responses to climate change. Also analysis on the extent to which existing policies addresses issues related to forest resources management with a focus on adaptation to climate change is needed.

\section{References}

[1] Agrawala, S, Moehner, A, Hemp, A, van Aalst, M, Hitz, S, Smith, J, Meena, H, Mwakifwamba, S, Hyera, T, and Mwaipopo, O. (2003): Development and Climate Change in Tanzania: $\quad$ COM/ENV/EPOC/DCD/DAC/(2003)5/Final, OECD, Paris.

[2] Alley R, Berntsent, Bindiff N. L, Chen Z, Chidthaisong A, Friedlingstein p, Gregory J, Hegerl G, Heimann M, Hewitson B, Hoskins B, Joos F, Jouzel J, Kattsov V, Lohmann U,
Manning M, Matsuno T, Molina M, Nicholls N, Overpeck J, Quin D, Raga G, Ramaswamy V, Ren J, Rusticucci M, Solomon S, Somerville R, Stocker T. F, Stott P, Stouffer R. J, Whetton P, Wood R. A, and Wratt D (2007). Climate Change 2007: The Physical Science Basis. Contribution of Working Group 1 to the Fourth Assessment Report of the Intergovernmental Pannel on Climate Change, Paris.

[3] AWF: Conserving Wildlife, Protecting Land, Empowering People: Washington, D.C. Centre (USA) - Annual Report 2003.

[4] FAO (2007) Adaptation to Climate Change in Agriculture, Forestry and Fisheries: Perspectives, Framework and Priorities: Rome: FAO.

[5] Gordana C. (2009), UNDP GEF project develops Watershed Management Plan for the PrespaReaginal Project - Republic of Macedonia visited at www.prespapark.orgin 2012.

[6] Gouri, Sushil Mudgal, Elaine Morrison and James Mayers, Policy influences on forest-based livelihoods in Himachal Pradesh, India. SIDT and IIED, 2004. http://www.iied.org/NR/forestry/projects/india.html Accessed September, 2012.

[7] Handeni Integrated Agroforestry Project - HIAP (2000): Annual Progress Report presented for discussions by members of the district council.

[8] Harvey, C. A. and Haber, W. A. (1999). Remnant trees and the conservation of biodiversity in Costa Rican pastures. Agroforestry Systems 44:37-68.

[9] Kingdon, J. \& K. M. Howell (1993): Mammals of the forests of eastern Africa. in Lovett, J. C. \& S. K. Wasser (eds): Biogeographyand Ecology of the Rain Forests of Eastern Africa. Cambridge University Press, Cambridge.

[10] Larson et al, (2007) "Role of Forests in Carbon Cycles, Sequestration and Storage: Climate Change Mitigation, Forest Management and Effects on Biological Diversity" Newsletter No. 5: Canada.

[11] Sanderson Michael, SantiniMonia, Valentini Riccardo and Pope Edward (2012) Relationships between forests and weather EC Directorate General of the Environment 13th January.

[12] White S. (2002): IUCN Mount Elgon Conservation and Development Project. Nairobi, Kenya \& IUCN, Gland, Switzerland and Cambridge, UK.

[13] UNEP - United Nations Environment Programme (2001): Global Environment Outlook 3. Accessed at www.unep.org/geo in June 2013. 